\title{
Soft skill communication and prospective bachelor
}

\author{
Mazdalifah $^{1 *}$, Fatma Wardy Lubis ${ }^{1}$, Munzaimah Masril ${ }^{1}$ \\ ${ }^{1}$ Program Studi Ilmu Komunikasi Fakultas Ilmu Sosial Dan Ilmu Politik Universitas Sumatera \\ Utara \\ *Email: mazdalifah@usu.ac.id
}

\begin{abstract}
Soft Skill communication skills are very important for prospective scholars. These abilities are useful in dealing with the world of work, such as during interviews, convey ideas well, and are able to negotiate and looby. The training was attended by 150 participants from various faculties at the University of North Sumatra such as: Faculty of Mathematics and Natural Sciences, Faculty of Economics, Faculty of Engineering, Faculty of Agriculture, Faculty of Law, Faculty of Cultural Sciences. The training method uses the method of delivering two-way communication and material simulation. The result of this community service activity is the increased knowledge and skills of Soft Skill Communication candidates for the University Sumatra Utara candidate in the face of the workforce.
\end{abstract}

Keyword: Soft skills, Communication, Prospective Bachelor, University Sumatra Utara

\begin{abstract}
Abstrak
Kemampuan Soft Skill komunikasi sangat penting bagi calon sarjana. Kemampuan tersebut bermanfaat dalam menghadapi dunia kerja, seperti saat wawancara, menyampaikan gagasan dengan baik, serta mampu melakukan negosiasi dan looby. Pelatihan ini diikuti oleh 150 orang peserta dari berbagai fakultas di Universitas Sumatera Utara seperti : Fakultas FMIPA, Fakultas Ekonomi, Fakultas Teknik, Fakultas Pertanian, Fakultas Hukum, Fakultas Ilmu Budaya. Metode pelatihan menggunakan metode penyampaian komunikasi dua arah dan simulasi materi. Hasil kegiatan pengabdian ini adalah bertambahnya pengetahuan dan keterampilan Soft Skill Komunikasi calon sarjana Universitas Sumatera Utara dalam menghadapi dunia kerja.
\end{abstract}

Kata Kunci : Soft skills, Komunikasi, Calon Sarjana, Universitas Sumatera Utara

\section{PENDAHULUAN}

Calon sarjana adalah mahasiswa yang memasuki akhir masa kuliah dan bersiap-siap memasuki dunia kerja. Sisuasi dunia kerja yang semakin kompetitif membuat peluang kerja semakin sempit. Calon sarjana harus memiliki keunggulan tertentu, agar mampu bersaing dengan calon lainnya. Salah satu kemampuan yang penting dimiliki adalah kemampuan komunikasi atau Soft Skill utamanya Soft Skill Komunikasi. Hasil penelitian di Harvard University Amerika Serikat, menunjukkan bahwa kesuksesan sesorang tidak ditentukan semata-mata oleh kemampuan mengelola hal teknis semata (hard skills), tetapi lebih pada kemampuan mengelola diri dan orang lain (soft skills). Hasil penelitian menyimpulkan bahwa kesuksesan dalam kerja ditentukan oleh 20 persen hard skills dan 80 persen soft skills.

Hasil penelitian tersebut di atas membuktikan bahwa kemampuan Soft Skill lebih dipentingkan dibandingkan kemampuan Hard Skill. Salah satu kemampuan Soft Skill adalah kemampuan berkomunikasi yang baik. Komunikasi merupakan kunci sukses dalam dunia kerja. Siapa yang mampu berkomunikasi dengan baik, maka kesuksesan akan dapat diraih. Sebuah survey di Michigan University melaporkan bahwa faktor-faktor yang menentukan sukses sebuah organisasi adalah:

1) Keterampilan dan komunikasi lisan dan tertulis; 

2) Kepemimpinan;
3) Kemampuan analitis;
4) Bekerja dalam tim;
5) Kemampuan menangani perubahan;
6) Rasa sosial, professional;
7) Manajemen keuangan.

Apakah kemahiran soft skills komunikasi tersebut? Pengertian soft skills mengacu pada seperangkat kemampuan yang mempengaruhi bagaimana kita berinteraksi dengan orang lain. Soft skills komunikasi berisi tentang komunikasi efektif dengan atasan, rekan sejawat ataupun dengan orang-orang yang menjadi bawahan kita. Banyak situasi dalam dunia kerja membutuhkan negosiasi dan looby, agar maksud dan tujuan organisasi tercapai. Oleh sebeb itu Spft Skill Komunikasi merupakan kunci sukses organisasi dalam mencapai tujuannya. bincang-bincang dengan calon sarjana menemukan kegagalan dalam tahap wawancara.

Kegagalan yang sering dialami oleh pencari kerja dalam sessi wawancara menunjukkan calon sarjana belum memiliki kemampuan Soft Skill komunikasi yang baik. Fenomena ini mendorong tim pengabdian untuk melakukan kegiatan pengabdian masyarakat. Kemahiran (kompetensi) soft skills komunikasi dapat ditingkatkan dengan cara learning by doing, belajar berdasarkan pengalaman sehari-hari. Seseorang akan belajar berdasarkan pengalaman yang dialaminya setiap hari. Bila terjadi kesalahan atau kendala maka seseorang tersebut akan memperbaiki dan mencobanya kembali. Kedua, mengikuti berbagai pelatihan dan seminar. Pelatihan dan seminar adalah cara praktis dalam meningkatkan soft skills seseorang.

Selama ini tim pengabdian telah mempunyai pengalaman pengabdian sebagai narasumber dalam berbagai pertemuan dan pelatihan yang berkaitan dengan public speaking di kota Medan. Tim pengabdian berpengalaman dalam mengelola praktek komunikasi di tingkat laboratorium Ilmu Komunikasi. Penyelenggaraan pelatihan terhadap mahasiswa calon sarjana tentang kemahiran (kompetensi) soft skills dalam bidang komunikasi, diharapkan dapat menjadi bekal dalam memasuki dunia kerja.

\section{METODE PELAKSANAAN}

Pelatihan ini menggunakan metode partisipatif, dimana peserta pelatihan diajak untuk terlibat aktif dalam setiap sessi. Misalnya pada sessi penyampaian materi, peserta diajak untuk bermain games dan diminta untuk menyampaikan pendapat berdasarkan pengalamannya. Pada sessi simulasi atau praktek, peserta diminta berperan sebagai Talent dalam mempraktekkan wawancara, negosiasi, public speaking dan lobby. Ada beberapa tahapan pelaksanaan yaitu :

1) Tahap pertama. Tim mempersiapkan pelatihan dengan cara melakukan rapat-rapat persiapan, membagi tugas dan kerja sesuai tupoksi masing-masing.

2) Tahap kedua mendisain dan menyebarluaskan flyer kegiatan pelatihan soft skill komunikasi . Flyer ini akan di sebar luaskan ke beberapa media di lingkungan USU agar informasi pelatihan tersebar luas dengan baik melalui media infofisip dan usulibrary . Akhirnya didapat jumlah peserta pelatihan 150 orang. Peserta pelatihan terdiri dari berbagai mahasiswa calon sarjana dai berbagai fakultas seperti : Fakultas Ilmu Budaya, Fakultas Pertanian, Fakultas Hukum, Fakultas Teknik, Fakultas Ekonomi dan Bisnis, Fakultas Kedokteran Gigi, Fakultas Matematika dan Ilmu Pengetahuan Alam, Fakultas Ilmu Sosial dan Ilmu Politik, Fakultas Kesehatan Masyarakat, Fakultas Farmasi, Fakultas Psikologi, Fakultas Keperawatan, Fakultas Ilmu Komputer dan Teknologi Informasi, dan Fakultas Kehutanan.

3) Tahap ketiga, melakukan pelatihan soft skill komunikasi kepada mahasiswa calon sarjana selama tiga hari dari tanggal 29 juli sampai 31 Juli di Aula Serbaguna FISIP USU. Hari pertama pemberian materi oleh praktisi Millie Desky membawa materi wawancara efektif, 
dan Erliza Rizki Firdaus membawakan materi presentasi efektif dan penampilan diri . Hari kedua pemberian materi oleh Tim pengabdian yaitu teknik negosiasi oleh Dra. Fatmawardy Lubis dan Lobby oleh Munzaimah Masril M Ikom. dan materi public speaking oleh Mazdalifah Ph.D. Hari ketiga, peserta dibagi atas tiga kelompok untuk melakukan simulasi praktek wawancara efektif, presentasi menarik disertai negosiasi dan lobby, , dan public speaking. Peserta pelatihan dibagi atas tiga kelompok, yaitu kelompok public speaking, kelompok wawancara kerja, dan kelompok negosiasi dan lobby. Masingmasing kelompok didampingi oleh satu orang tim pengabdian, selama lebih kurang 2 jam. Acara pelatihan ditutup dengan penampilan wakil dari masing-masing kelompok, dimana penampilan ini akan di evaluasi oleh seluruh peserta. Secara keseluruhan pelatihan ini dirancang dengan teknik partisipatif, peserta dilibatkan secara aktif dalam semua kegiatan pelatihan. Pelatihan ini juga diselingi permainan-permainan (games) menarik yang dapat merangsang partisipasi peserta.

\section{HASIL DAN PEMBAHASAN}

Hasil kegiatan pengabdian masyarakat ini adalah sebagai berikut : Peserta menyatakan bahwa isi materi pelatihan sangat relevan dan sesuai dengan harapan mereka. Artinya sesuai dengan apa yang mereka inginkan, sebagai calon sarjana dan pencari kerja yang akan melamar ke berbagai instansi atau perusahaan. Materi yang disajikan membantu peserta untuk mengetahui apa saja yang menjadi perhatian dalam wawancara kerja, cara bicara, cara duduk, cara berbicara dan lain sebagainya. Pengetahuan semacam ini membuat peserta menjadi tahu apa yang harus dilakukan dan apa yang tidak boleh dilakukan saat menghadapi sessi wawancara, negosiasi dan lobby saat melamar sebuah pekerjaan.

Peserta menilai penyampaian materi pelatihan yang disampaikan oleh beberapa pembicara, dari praktisi dan teoritisi sangat menguasai bidangnya dan menarik dalam tata cara penyampaian. Apalagi pemateri dari kalangan praktisi mampu menyampaikan contoh nyata berdasarkan pengalamannya dalam menyeleksi pelamar kerja. Peserta menilai bahwa materi yang disampaikan menarik dan mudah untuk diimplementasikan. Penyampaian yang menarik karena diselingi dengan permainan yang mampu mencairkan suasana menjadi hidup dan semangat. Pemateri juga menampilkan contoh cara berjalan, duduk, dan bicara saat sessi wawancara, memilih pakaian yang tepat saat wawancara, riasan yang sesuai dengan situasi wawancara, asesoris yang dipakai, dan sebagainya. Pemateri melakukan beberapa koreksi penampilan terhadap beberapa peserta, mana yang dianggap sudah baik dan mana yang harus diperbaiki. Peserta menilai hal-hal sederhana seperti ini bermanfaat buat mereka dan mudah untuk diterapkan.

Pelatihan Soft Skill Komunikasi bagi calon sarjana di Universitas Sumatera Utara mendapat kesempatan untuk bertanya seputar materi yang disampaikan oleh pembicara. Sessi ini mendapat perhatian besar dari peserta. Banyak hal yang mereka tanyakan. Misalnya, bagaimana melakukan lobby dan negosiasi dalam menentukan besaran gaji dan jaminan kesehatan, pakaian apa yang sesusi bagi pemakai jilbab saat wawancara, mengatasi gugup saat harus mempresentasikan rencana kerja, dan sebagainya. Peserta terlihat bersemangat dalam mengajukan pertanyaan-pertanyaan. Mereka menyatakan bahwa jawaban-jawaban yang diberikan oleh pemateri sangat memuaskan. Peserta pelatihan mendapat kesempatan untuk melakukan simulasi / praktek di hari ke tiga. Peserta dibagai tiga kelompok yang terdiri dari kelompok wawancara, kelompok negosiasi dan lobby, serta kelompok public speaking. Masing-masing kelompok diberi kesempatan selama dua jam untuk berdiskusi dan memilih anggotanya yang akan mewakili kelompok nantinya. Sessi simulasi ini mendapat perhatian yang amat besar dari peserta, mereka saling mengenalkan terlebih dahulu, menciptakan yel-yel kelompok, dan berlatih mempraktekkan sesuai pilihan panitia. Tim pengabdian turut mendampingi peserta dalam simulasi ini, memberi arahan bagaimana melakukan praktek dengan benar, memimpin diskusi dalam memutuskan sesuatu. Peserta mengatakan bahwa 
fasilitator cukup membantu dalam simulasi, dan alokasi waktu selama dua jam dianggap sudah maksimal dalam melakukan simulasi.

Kegiatan pengabdian masyarakat ini menghasilkan luaran sebagai berikut : 1. Pubblikasi kegiatan pelatihan dalam bentuk video, di media on line Harian Tribun Medan dengan judul Mazdalifah dkk melakukan kegiatan pengabdian masayarakat. Hasil luaran lainnya adalah video pengabdian pada masyarakat yang akan di sebarluaskan di You Tube. Karya ilmiah dalam bentuk tulisan dalam seminar nasional pengabdian masyarakat nasional di Lombok yang diselenggrakan oleh Universitas Mataram berlangsung pada tanggal 17 Oktober 2019, dan tulisan ilmiah dalam jurnal pengabdian masyarakat dari Lembaga Pengabdian Universitas Sumatra Utara.

\section{KESIMPULAN}

Kegiatan pengabdian Pelatihan Soft Skill bagi mahasiswa calon sarjana Universitas Sumatera menyimpulkan :

1. Pengetahuan mahasiswa calon sarjana di Universitas Sumatera Utara bertambah tentang soft skill komunikasi semakin bertambah.

2. Adanya kesadaran dalam diri mahasiswa calon sarjana di Universitas Sumatera Utara bahwa kemampuan intelektual tidak cukup dalam memasuki dunia kerja, harus diiringi dengan kemampuan soft skill dalam menghadapi dunia kerja.

3. Mahasiswa mempunyai nilai tambah dimana kemampuan soft skill mahasiswa calon sarjana semakin terasah dalam memasuki dunia kerja.

Maka saran pada pengabdian ini adalah :

1. Adanya keinginan peserta untuk menambah materi soft skill yang lebih banyak. Misalnya : pelatihan dalam menulis Curiculum Vitae.

2. Waktu untuk melakukan simulasi atau praktek dalam pelatihan ditambah, agar praktek bisa dilakukan dengan lebih leluasa dan nyaman.

\section{UCAPAN TERIMAKASIH}

Artikel ini merupakan salah satu hasil dari Program Pengabdian kepada Masyarakat yang Dibiayai oleh dana NON PNBP Universitas Sumatera Utara Sesuai dengan Surat Perjanjian Penugasan Pelaksanaan Pengabdian kepada Masyarakat Program Mono Tahun Dosen Muda Tahun Anggaran 2019. Oleh karena itu, diucapkan terima kasih kepada Rektor Universitas Sumatera Utara atas dukungan dana dan fasilitas yang diberikan. Terima kasih juga kepada Mitra pada kegiatan pengabdian ini.

\section{DAFTAR PUSTAKA}

Cangara, H. 2007. Pengantar Ilmu Komunikasi, Jakarta: Raja Grafindo Persada

DeVito, Yoseph A. 1997. Komunikasi Antar Manusia Kuliah Dasar, Jakarta : Professional Books

Ibrahim, Idi Subandy. 2007. Kecerdasan Komunikasi Seni Berkomunikasi Kepada Public, Bandung : Simbiosa Rekatama Media.

Mulyana, Deddy, Prof. Dr. 2004. Komunikasi Efektif Suatu Pendekatan Lintas Budaya, Bandung : Remaja Rosda Karya. 
Mulyana, Deddy, MA Ph.D. 2004. Ilmu Komunikasi Suatu Pengantar, Bandung : Remaja Rosda Karya.

Rogers, Natalie. 2004. Berani Bicara di Depan Public Cara Cepat Berpidato, Bandung : Nuansa

Hamid, Farid, Dr. Msi. Budianto , Heri. S.Sos. M.Si. ( Ed ). 2011, Ilmu Komunikasi Sekarang dan Tantangan Masa Depan, Jakarta : Kencana Prenada Media Group.

Haryadi Sebayang, Reva. (2017). Komunikasi Organisasi : Soft Skill dan Pengembangan, Tugas Mata Kuliah Komunikasi Orgtanisasi FISIP USU

Sinaga, Samuel D. (2017), Komunikasi Organisasi : Soft Skill, Tugas Mata Kuliah Komunikasi Organisasi FISIP USU

Shafinazh, Namira. (2017), Komunikasi Organisasi : Pentingnya Soft Skill dan Pengembangannya, Tugas Mata Kuliah Komunikasi Organisasi FISIP 